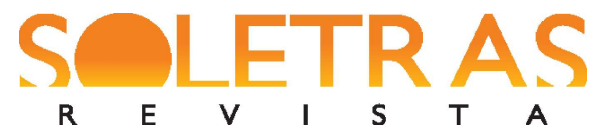

\title{
Entre agulhas e linhas: a metáfora de corte e costura em construções transitivas
}

\author{
Lilian Ferrari ${ }^{1}$ \\ Caroline Soares ${ }^{2}$
}

Resumo: Este artigo investiga a metáfora de corte e costura no português brasileiro, que constitui, tal como a metáfora do conduto (REDDY, 1979), um dos mapeamentos metafóricos disponíveis para a referência à comunicação verbal. A partir de dados de uso retirados do Twitter, argumenta-se que a metáfora COMUNICAÇÃO VERBAL É ATIVIDADE DE CORTE E COSTURA é normalmente aplicada à construção transitiva, engendrando duas extensões metafóricas: a extensão transitiva prototípica, instanciada pelos verbos alfinetar e tesourar, e a extensão transitiva resultativa, instanciada pelos verbos alinhavar, costurar, tecer, tricotar. Com o objetivo de investigar a produtividade da metáfora de corte e costura, a análise enfoca a frequência de sentidos literais e metafóricos para cada grupo de construções. Os resultados indicam que as extensões metafóricas de transitivas prototípicas, instanciadas por alfinetar e tesourar, são mais frequentes que suas contrapartes literais. Já as transitivas resultativas dividem-se em dois grupos: aquelas instanciadas por costurar e tricotar predominam em usos literais, já aquelas instanciadas por alinhavar e tecer ocorrem predominantemente em usos metafóricos.

Palavras-chaves: comunicação verbal; metáfora de corte e costura; construção transitiva; extensão metafórica.

\section{Introdução}

Uma das metáforas clássicas na literatura cognitivista é a chamada Metáfora do Conduto, identificada por Reddy (1979) e retomada por Lakoff \& Johnson (1980), que concebe a comunicação verbal como transferência de um objeto de um doador para um receptor (por ex, dar uma ideia a alguém). Embora esse tipo de conceptualização tenha papel central na conceptualização da comunicação verbal, e produtividade reconhecida em inglês e outras línguas, como francês, italiano e holandês (MORRIS \& WALDMAN, 2011), a

\footnotetext{
${ }^{1}$ Doutorado em Linguística pela Universidade Federal do Rio de Janeiro/University of Southern California, Los Angeles/ (1994), e Pós-doutorado na University of California, Berkeley (2006). Atualmente é Professora Titular do Departamento de Linguística e Filologia e membro permanente do Programa de Pós-Graduação em Linguística da Universidade Federal do Rio de Janeiro. Rio de Janeiro, Brasil. E-mail: lilianferrari@uol.com.br. ORCID iD: 0000-0001-7808-4425.

${ }^{2}$ Doutora em Linguística pela Universidade Federal do Rio de Janeiro (2019). Possui Mestrado em Estudos da Linguagem (2013), Especialização em Leitura e Produção de textos (2005) e em Língua Portuguesa (2007) pela Universidade Federal Fluminense. Rio de Janeiro, Brasil. E-mail: caroline.soares@gmail.com. ORCID iD: 00000001-6994-7997.
} 
Metáfora do Conduto é apenas uma das possibilidades de conceptualização metafórica da comunicação verbal.

Este trabalho enfoca uma outra possibilidade de mapeamento metafórico que se mostra produtivo no português brasileiro, em que a comunicação verbal é concebida como atividade de corte e costura ${ }^{3}$. O objetivo é analisar usos associados a esse mapeamento metafórico, tais como alfinetar alguém ou alinhavar uma proposta. Nesses casos, verbos associados ao domínio de corte e costura são instanciados em extensões metafóricas de comunicação verbal, projetadas a partir da construção transitiva literal (por exemplo, "As costureiras alinhavaram/alfinetaram o vestido"). Com base em exemplos atestados no uso, a partir de dados do Twitter, a análise busca destacar a distribuição das extensões metafóricas de corte e costura no corpus analisado.

O trabalho está organizado em três seções principais. A seguir, os pressupostos teóricos da pesquisa são apresentados, destacando-se trabalhos pioneiros sobre metáfora, sob a perspectiva da Linguística Cognitiva (LAKOFF \& JOHNSON, 1980; REDDY, 1979), bem como desdobramentos posteriores do tema, relacionados à noção de mesclagem conceptual no âmbito da Teoria dos Espaços Mentais (FAUCONNIER, 1994; FAUCONNIER \& TURNER, 2002). Na seção subsequente, a metodologia é detalhada, especificando-se a origem dos dados, objetivos e hipóteses da pesquisa. Por fim, apresenta-se a análise, em que são descritos dois tipos de extensões metafóricas relacionadas à metáfora de corte e costura, associada à comunicação verbal. Essas extensões tomam como ponto de partida duas construções transitivas instanciadas por verbos de corte e costura, a construção transitiva prototípica e a construção transitiva resultativa. Os resultados evidenciam a produtividade da metáfora de corte e costura no português brasileiro, indicando que, embora ambas as construções apresentem usos literais e metafóricos, as extensões metafóricas predominam na maioria dos casos.

\footnotetext{
${ }^{3} \mathrm{~A}$ metáfora de corte e costura no português brasileiro já foi atestada em trabalhos anteriores (FERRARI \& PINHEIRO, 2015; FERRARI, 2020). Esses trabalhos enfocam a construção cognitiva do significado em termos dos processos de mesclagem conceptual ativados pelas extensões metafóricas. A contribuição do presente artigo, por outro lado, é contrastar a produtividade das instanciações dos verbos de corte e costura em construções transitivas literais e metafóricas.
} 


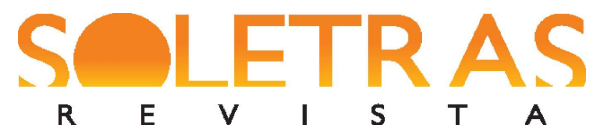

\section{Pressupostos teóricos}

O livro Metaphors we live by (LAKOFF \& JOHNSON, 1980) representa uma ruptura com relação à concepção tradicional de metáfora como 'figura de linguagem', vinculada a textos literários e usos mais elaborados da língua. $\mathrm{Na}$ verdade, ao utilizar a expressão 'metáfora conceptual', Lakoff \& Johnson (1980) adotam a perspectiva de que as metáforas são formas de pensar, e não apenas expressões linguísticas. Além disso, ao tratar de metáforas produtivas no uso cotidiano do inglês, os autores deixam claro o caráter conceptual e não estritamente linguístico desses processos. Em linhas gerais, o processo metafórico é descrito como o mapeamento entre domínios ${ }^{4}$ : de um domínio-fonte (mais concreto) e um domínioalvo (mais abstrato), de modo que as expressões metafóricas são descritas como reflexos linguísticos desses mapeamentos cognitivos. ${ }^{5}$

Um importante marco inicial no tratamento da metáfora como processo cognitivo foi a caracterização da Metáfora do Conduto (REDDY,1979), descrita um ano antes da publicação de Metaphors we live by. Segundo Reddy, várias expressões e sentenças do inglês indicam que a comunicação verbal é concebida metaforicamente como transferência de objeto de um doador para um receptor. Por exemplo, uma sentença como He gave an idea to his friend ("Ele deu uma ideia a seu amigo") retrata a comunicação como uma ação realizada por um doador ("he/ele") que transfere um objeto ("idea/ideia") para um receptor ("his friend/seu amigo"). Como, na realidade, ideias não são objetos, e não há garantia de que a ideia na mente do falante seja integralmente reproduzida na mente do ouvinte, fica evidente que se trata de uma conceptualização metafórica.

Nos termos de Lakoff \& Johnson (1980), a Metáfora do Conduto envolve o seguinte mapeamento entre o domínio-fonte e o domínio-alvo:

\footnotetext{
${ }^{4}$ Nos termos da Linguística Cognitiva, domínios são estruturas conceptuais que podem incluir experiências perceptuais, conceitos, complexos conceptuais e sistemas elaborados de conhecimento.

${ }^{5}$ Lakoff \& Johnson (1980) ressaltam que a metáfora conceptual é um processo cognitivo de mapeamento entre domínios, enquanto as expressões metafóricas são expressões linguísticas. Casasanto (2013) propõe a utilização dos termos metáfora mental e metáfora linguística, respectivamente, para destacar essa diferença. Por exemplo, a metáfora TEMPO É ESPAÇO é uma metáfora mental, que se reflete em metáforas linguísticas tais como "O tempo voa", "O Natal vai chegar rápido", etc.
} 


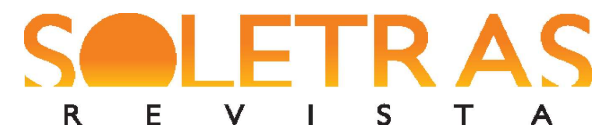

N. $41-2021.1$ - LILIAN FERRARI

CAROLINE SOARES

DOMÍNIO-FONTE

DOMÍNIO-ALVO

TRANSFERÊNCIA FÍSICA

COMUNICAÇÃO

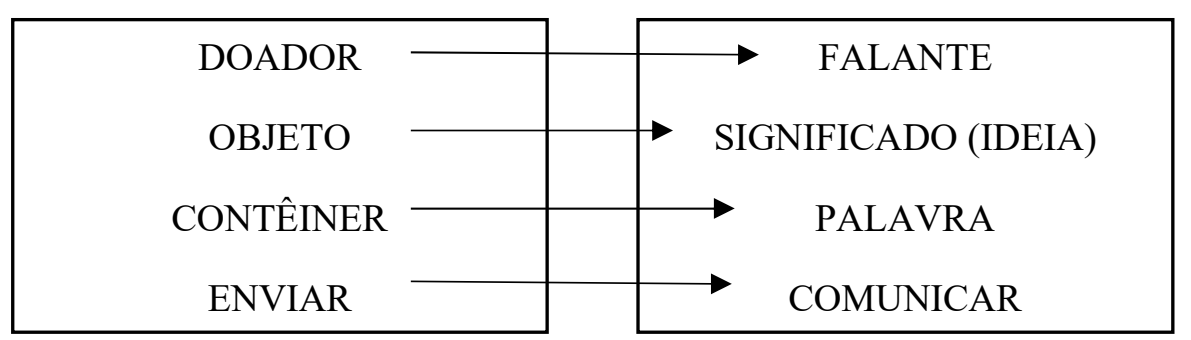

Figura 1: Projeção entre domínios na Metáfora do Conduto.

O mapeamento representado na Figura 1 permite a conceptualização do domínio-alvo de Comunicação Verbal, a partir do domínio-fonte de Transferência Física. Esse mapeamento é produtivo não apenas em inglês, mas em várias outras línguas (MORRIS \& WALDMAN, 2011). No caso do Português, podemos elencar os seguintes exemplos:

(1) Você pegou o que eu disse?

(2) Ela colocou as suas principais ideias no texto.

(3) Ele pronunciava palavras ocas.

O exemplo (1) retrata o significado linguístico como um objeto que o ouvinte poderia pegar, de modo que o falante é concebido como aquele que transfere o objeto (doador) e o ouvinte como aquele que o recebe (receptor). Assim, 'compreender o significado' é conceptualizado em termos de 'pegar um objeto'. No exemplo (2), as ideias também são tratadas como objeto, que pode ser colocado em uma base concreta, de modo que o texto é conceptualizado em termos de recipiente. Em (3), as palavras são concebidas como contêineres, que podem estar ocas e não conter nenhum objeto (significado). Nos termos de Dancygier \& Sweetser (2014), pode-se considerar que cada um dos exemplos acima adota diferentes pontos de vista no acesso ao domínio-fonte, colocando em proeminência aspectos distintos desse domínio. Nos termos de Langacker (1987, 1991), o que se verifica é que os exemplos caracterizam diferentes construals, que representam formas alternativas de acesso ao conjunto estruturado de conhecimento que estrutura o domínio de TRANSFERÊNCIA FÍSICA. 
Com o desenvolvimento da Teoria dos Espaços Mentais (FAUCONNIER, 1994, 1997), que deu origem à Teoria da Mesclagem Conceptual (FAUCONNIER \& TURNER, 1998, 2000, 2002; TURNER, 2014), a Metáfora do Conduto, de forma análoga a outros mapeamentos metafóricos, pôde ser caracterizada como um processo de mesclagem conceptual envolvendo quatro espaços mentais. Além dos dois espaços iniciais, o processo envolve um espaço genérico, em que são representados os elementos compartilhados entre esses espaços e, em especial, um espaço-mescla, onde é representado o significado novo que emerge da metáfora (FAUCONNIER \& TURNER, 2002). A representação resultante é a seguinte:

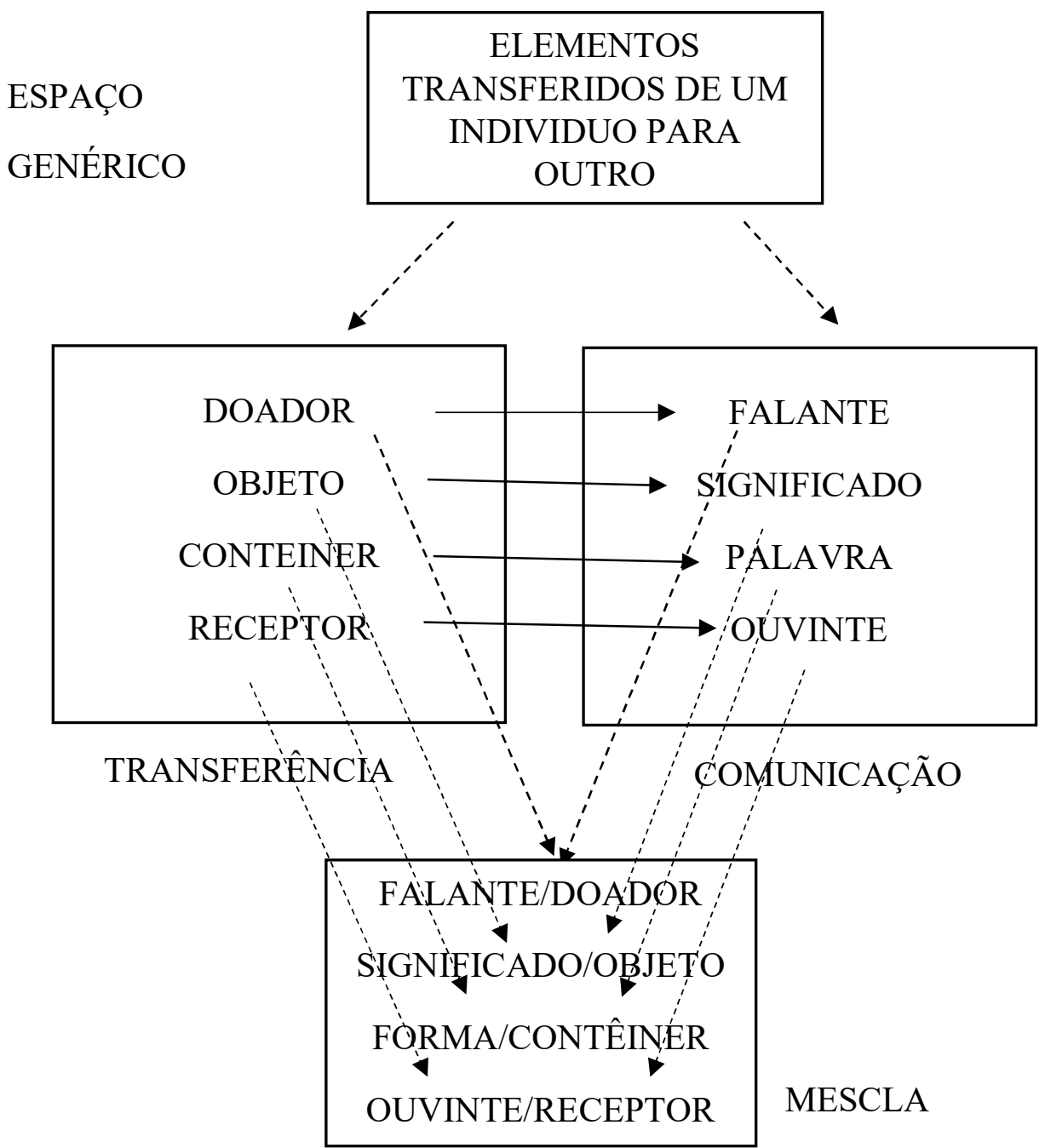

Figura 2 - Mesclagem Conceptual na Metáfora do Conduto. 


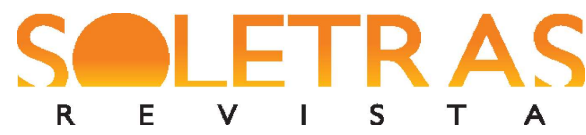

Como indica a Figura 2, na mescla, a comunicação é transferência de objeto de um indivíduo (falante/doador) para outro (ouvinte/receptor). Isso ocorre porque a projeção de elementos provenientes dos espaços iniciais forma uma nova configuração, permitindo que novas relações sejam forjadas.

A estrutura emergente cria novo significado, de modo que a comunicação verbal, ao invés de ser enquadrada como o fenômeno complexo que realmente é, envolvendo processos cognitivos elaborados, passa a ser concebida como um processo relativamente simples e direto como a entrega de um pacote a alguém. A metáfora, portanto, facilita a referência à comunicação verbal na linguagem cotidiana.

Embora a Metáfora do Conduto seja bastante produtiva em português, a língua disponibiliza uma outra metáfora para a comunicação verbal. Nesse caso, o domínio-fonte deixa de ser a transferência física, e passa a envolver atividades de corte e costura, envolvendo linhas, tecidos, agulhas, alfinetes, entre outros. Ferrari (2020) denominou esse processo de Metáfora de Corte e Costura, descrevendo-o com base em processos de mesclagem distintos, em função de aspectos da atividade de corte e costura que podem ser colocados em proeminência, gerando estruturas emergentes específicas. Assim, as atividades relacionadas a 'corte' permitem conceptualizar metaforicamente a comunicação como capaz de afetar as relações interpessoais, enquadrando negativamente a imagem social dos indivíduos envolvidos. É o que ocorre em casos como alfinetar ou tesourar alguém, com sentidos aproximados de criticar e falar mal, respectivamente. Já as atividades relacionadas à costura/tessitura são recrutadas para conceptualizar metaforicamente a comunicação como colaborativa e construída passo-a-passo. É o caso de expressões como costurar um acordo, alinhavar um comentário, etc.

Ferrari (2020, p. 28-30) ressalta, ainda, que esses dois tipos de conceptualização estão associados a dois tipos de construção transitiva, a construção transitiva prototípica e a construção transitiva resultativa (IBBOTSON et al., 2012; DIESSEL, 2015): 


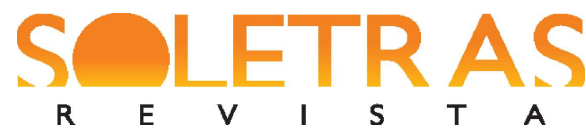

\section{Construção Transitiva}

Construção Transitiva Prototípica

\begin{tabular}{|lccc|}
\hline Polo sintático & SN & V & SN \\
Polo semântico & $X$ & AFETA & Y \\
\hline
\end{tabular}

TESOURAR

ALFINETAR

\section{Construção Transitiva Resultativa}

\begin{tabular}{|lccc|}
\hline Polo sintático & SN & V & SN \\
Polo semântico & X & CRIA & Y \\
& & & \\
\hline
\end{tabular}

$\Downarrow$

Figura 3: Construções transitivas e verbos de corte e costura.

Como apresentado na Figura 3, a Construção Transitiva Prototípica pode ser instanciada pelos verbos tesourar e alfinetar. Nesse caso, o objeto direto é afetado pela ação realizada. Assim, a semântica de tesourar sugere que o tecido perde sua estrutura original de forma irreversível (por ex., tesourar o vestido), enquanto o uso de alfinetar indica que o tecido é afetado, mas de modo superficial e reversível (por ex., alfinetar a bainha da saia). A Construção Transitiva Resultativa, por sua vez, pode ser instanciada pelos verbos alinhavar, costurar, tecer e tricotar: nesse caso, o objeto direto resulta da ação. A semântica dos verbos, em cada caso, acrescenta inferências específicas à atividade realizada: enquanto o verbo alinhavar enquadra o resultado como provisório, o verbo costurar já se refere a um resultado definitivo; com tecer, as inferências são de que se trata de uma ação mais detalhada, que se estende no tempo, enquanto tricotar também remete a uma ação prolongada, em que há movimento alternado de agulhas.

No caso das extensões metafóricas de corte e costura, a Construção Transitiva Prototípica envolve o frame de corte e costura, no Input 1, perfilando o agente, as ações que envolvem corte na atividade de corte e costura (no caso, alfinetar ou tesourar) e o paciente (no caso, um tecido ou algo do gênero). Esses elementos são projetados em contrapartes no 
Input 2, de modo que o agente é projetado no falante, a atividade de corte e costura corresponde à fala, e o paciente é mapeado no ouvinte ou uma terceira pessoa:

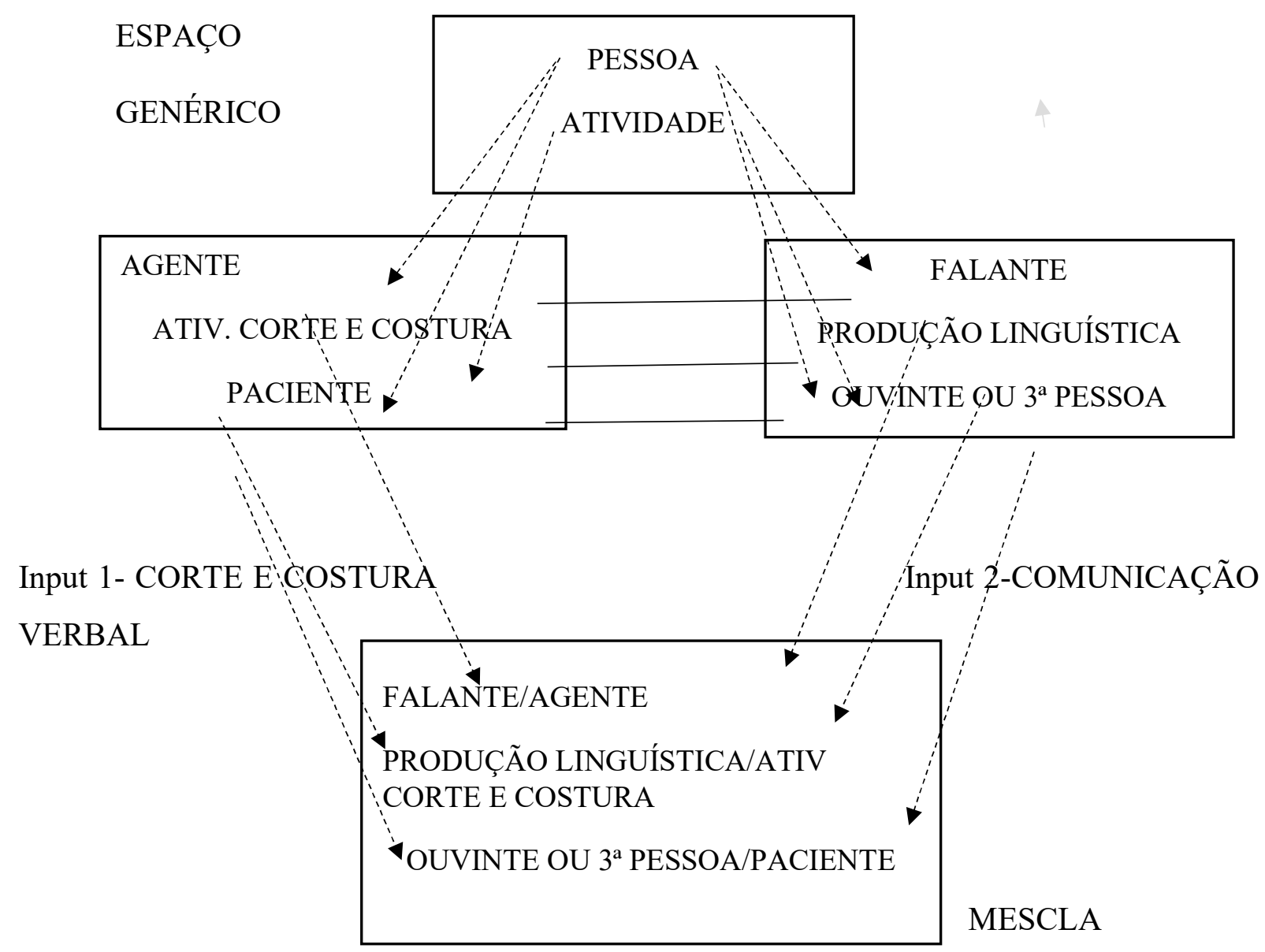

Figura 4: Mesclagem Conceptual referente à Construção Transitiva Prototípica.

$\mathrm{Na}$ mescla representada na Figura 4, o falante é agente, a fala é atividade de corte e costura e um outro indivíduo é paciente, ou seja, é afetado pela fala/ação.

Já na extensão metafórica Resultativa, o frame de corte e costura, no Input 1, é acessado a partir do agente, a atividade específica de costura/tessitura (alinhavar, costurar, tecer, etc.) e o resultado (no caso, um produto da atividade realizada). Esses elementos são projetados em contrapartes no Input 2: o agente é projetado no falante, a atividade de corte e costura na fala propriamente dita, e o resultado na mensagem: 


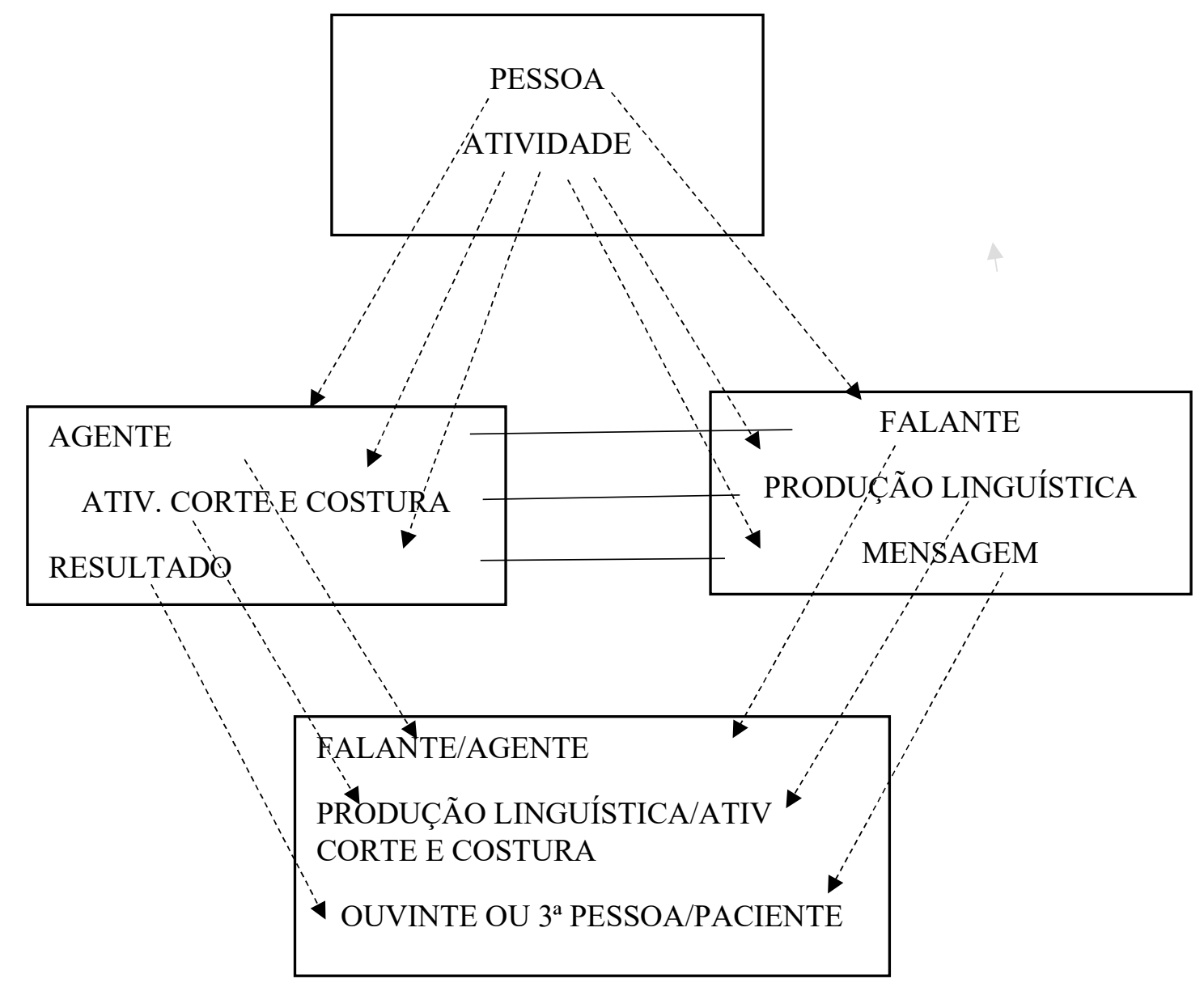

Figura 5: Mesclagem Conceptual referente à Construção Resultativa

Na mescla representada na Figura 5, o falante é agente, a fala é atividade de costura e a mensagem é resultado, ou seja, é criada pela fala/ação.

Esses usos, por sua vez, fazem parte de uma rede construcional associada às construções transitivas (IBBOTSON et al., 2012; DIESSEL, 2015), que servem de base para extensões metafóricas de significado. Tendo em vista que alguns lexemas podem passar por múltiplos mapeamentos metafóricos, e serem altamente polissêmicos (DIESSEL, 2019, p. 103), outras extensões metafóricas instanciadas por verbos de corte e costura podem ocorrer, como será descrito na análise. Por outro lado, itens linguísticos que são frequentemente usados em conjunto, associados entre si, constituem unidades de processamento automatizadas, conhecidas como chunks (BYBEE, 2010, p. 33-45). A automatização, por sua vez, é um processo contínuo, de modo que há vários graus de constituência (BYBEE \& 
SCHEIBMAN, 1999), envolvendo a força das ligações sequenciais entre itens lexicais, contingente à frequência. Assim, quanto mais uma determinada palavra é seguida por outra, mais estreita a associação sequencial entre elas. No que se refere às estruturas sintáticas, há uma maior complexidade, já que essas construções costumam ser parcialmente esquemáticas, como é o caso da construção transitiva SUJEITO-VERBO-OBJETO, que pode ser parcialmente preenchida no segmento VERBO-OBJETO, com diferentes graus de idiomatização. Por exemplo, tanto rasgar o verbo ("reclamar veementemente de algo ou alguém") quanto alinhavar um acordo ("estabelecer interações comunicativas com o objetivo de começar a produzir um acordo") são idiomatizados no português brasileiro, sendo que o primeiro em grau maior do que o segundo.

Assim, nos casos em que a frequência das extensões metafóricas transitivas for maior do que suas contrapartes literais, é possível cogitar que essas extensões se acham rotinizadas na língua. De fato, como será apontado na análise, a distribuição de instanciações transitivas literais e metafóricas sugere que algumas extensões metafóricas são mais idiomatizadas do que suas contrapartes literais.

\section{Metodologia}

Com o objetivo de analisar a produtividade da metáfora de corte e costura nas construções transitivas do $\mathrm{PB}$, reuniram-se ocorrências literais e metafóricas retiradas do Twitter (https://twitter.com/explore), no período de abril de 2019 a outubro de 2020. A busca ocorreu a partir dos verbos de corte e costura alfinetar, tesourar, alinhavar, costurar, tricotar e tecer, e, a fim de reunir uma amostra representativa, foram selecionados os primeiros 100 casos de construções transitivas para cada verbo. Assim, obteve-se um total de 600 casos.

Com relação aos verbos selecionados, os sentidos literais e metafóricos dicionarizados (FERREIRA, 1986, 2010) são resumidos a seguir:

Tabela 1 - Sentidos literais e metafóricos dicionarizados dos verbos de corte e costura 
SOLETRAS

N. $41-2021.1$ - LILIAN FERRARI

CAROLINE SOARES

\begin{tabular}{|c|c|c|}
\hline $\begin{array}{llll}\text { VERBOS DE CORTE } & \text { E } \\
\text { COSTURA } & & & \end{array}$ & $\begin{array}{l}\text { SENTIDOS } \\
\text { DICIONARIZADOS } \\
\text { LITERAIS }\end{array}$ & $\begin{array}{l}\text { SENTIDOS } \\
\text { DICIONARIZADOS } \\
\text { METAFÓRICOS }\end{array}$ \\
\hline Alfinetar & $\begin{array}{l}\text { 1. Picar com alfinete. } 2 . \\
\text { Marcar uma(costura) com } \\
\text { alfinete. }\end{array}$ & $\begin{array}{l}\text { 1. Criticar, magoando. 2. Ferir } \\
\text { com palavras; satirizar. }\end{array}$ \\
\hline Tesourar & 1.Cortar com tesoura. & 1. Falar mal de. \\
\hline Alinhavar & $\begin{array}{l}\text { 1. Coser a ponto largo, como } \\
\text { preparo de costura que se fará } \\
\text { depois com ponto miúdo. }\end{array}$ & $\begin{array}{l}\text { 1. Preparar, aprontar, } \\
\text { improvisar: Alinhavou uma } \\
\text { desculpa por ter chegado } \\
\text { tarde. 2. Traçar os } \\
\text { lineamentos gerais de; } \\
\text { delinear; esboçar: Alinhavou o } \\
\text { romance para escrevê-lo mais } \\
\text { tarde. 3. Executar mal, } \\
\text { apressadamente: Entregou o } \\
\text { trabalho, mas reconheceu que } \\
\text { pudera apenas alinhavá-lo. }\end{array}$ \\
\hline Costurar & $\begin{array}{l}\text { 1. Coser 2. Unir com pontos } \\
\text { de costura. 2. Fazer trabalho } \\
\text { de costura. }\end{array}$ & $\begin{array}{l}\text { 1. Dirigir perigosamente no } \\
\text { trânsito, cortando (outros } \\
\text { veículos). 2. Fut. Desenvolver } \\
\text { jogo de dribles e passes curtos } \\
\text { bem coordenados por entre os } \\
\text { adversários, envolvendo-os. }\end{array}$ \\
\hline Tricotar & 1. Fazer com o tricô. & 1.Fazer intrigas; mexericar. \\
\hline Tecer & $\begin{array}{l}\text { 1. Entrelaçar regularmente os } \\
\text { fios de. 2. Fazer (teia ou } \\
\text { tecido) com fios. }\end{array}$ & $\begin{array}{l}\text { 1. Compor, entrelaçando, } \\
\text { trançar: Na mata virgem os } \\
\text { cipós tecem barreiras quase } \\
\text { intransponiveis. 2. Preparar, } \\
\text { engrendrar, armar, urdir: tecer } \\
\text { intrigas. 3. Coordenar, compor } \\
\text { (obra que exige cuidado e } \\
\text { trabalho): Teceu um belo } \\
\text { ensaio literário. 4. Levantar, } \\
\text { promover, provocar: tecer } \\
\text { disputas. 5. Mesclar, } \\
\text { entrecortar: A morte da filha } \\
\text { teceu de tristeza e saudade o } \\
\text { resto de seus dias. 6. Ornar, } \\
\text { ornamentar: As flores tecem a } \\
\text { mata de um belíssimo } \\
\text { colorido. 7. Fazer mexericos, } \\
\text { intrigas, tramas. }\end{array}$ \\
\hline
\end{tabular}




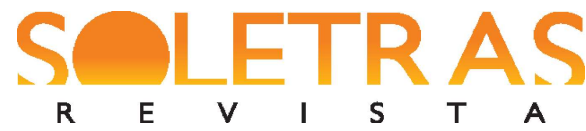

Os verbos de corte e costura listados na Tabela 1 ocorrem em extensões metafóricas de comunicação verbal, com exceção do verbo costurar cujas extensões metafóricas descritas referem-se aos domínios do trânsito e do futebol. Como se verá na análise, entretanto, todos os verbos de corte e costura apresentaram usos metafóricos de comunicação verbal, bem como outros usos metafóricos.

As hipóteses estabelecidas para a pesquisa foram as seguintes:

(i) A Metáfora de Corte e Costura licencia extensões metafóricas de comunicação verbal da construção transitiva.

(ii) Extensões metafóricas da construção transitiva envolvendo a Metáfora de Corte e Costura predominam em relação a outras extensões metafóricas instanciadas pelos mesmos verbos.

A hipótese (i) relaciona construções transitivas literais e extensões metafóricas dessas construções, a partir da Metáfora de Corte e Costura, associada ao domínio de comunicação verbal. A hipótese (ii), por sua vez, enfoca a produtividade da metáfora de corte e costura em relação a mapeamentos metafóricos referentes a outros domínios.

\section{Distribuição da metáfora de corte e costura nos dados}

Nesta seção, apresenta-se a distribuição de usos literais e extensões metafóricas de corte e costura nas construções transitiva prototípica e resultativa. Como se verá, a análise evidenciou, ainda, que os sentidos metafóricos não se restringem à metáfora de corte e costura, mas podem estar relacionados a outras metáforas.

\section{Construção Transitiva Prototípica}

No caso da Construção Transitiva Prototípica, observemos a distribuição encontrada para os verbos alfinetar e tesourar.

Com relação a alfinetar, a distribuição de usos literais e metafóricos é a seguinte: 


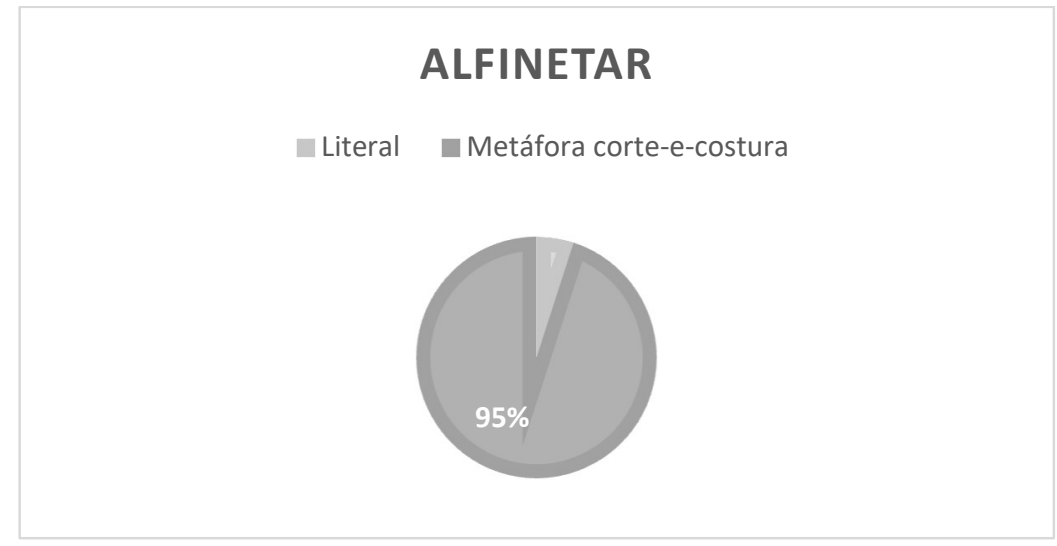

Gráfico 1 - Distribuição de usos do verbo alfinetar na Construção Transitiva Prototípica.

Como ilustra os gráficos acima, a instanciação do verbo alfinetar ocorre com usos literais em apenas 5\% dos casos:

(4) gente e essa q alfinetou o tecido com a agulha da maquina meu deus (https://twitter.com/rebecabcz/status/1231296280363720704)

Em (4), tem-se o sentido de furar levemente com um alfinete; trata-se do sentido literal do verbo, em um contexto de corte e costura. ${ }^{6}$

$\mathrm{Na}$ grande maioria dos casos (95\%), o verbo alfinetar, entretanto, é encontrado em extensões metafóricas. Vale notar, ainda, que não foram encontrados casos envolvendo outras metáforas; todos os usos metafóricos referem-se à metáfora de corte e costura:

(5) Angélica anuncia programa sobre simplicidade e é criticada nas redes.

"Com bilhões na conta é fácil", alfinetou humorista. (https://twitter.com/search?q=alfinetou\&src=typed_query)

No exemplo (5), a ação de alfinetar é interpretada como uma ação verbal que afeta negativamente aquele que é alvo do comentário. A sentença reporta uma crítica realizada pelo falante reportado (no caso, o humorista) à apresentadora Angélica; a contribuição semântica do verbo alfinetar é a de que se trata de uma crítica leve, mas capaz de causar desconforto.

Com relação ao verbo tesourar, a distribuição é a seguinte:

\footnotetext{
${ }^{6}$ Nesse grupo, foram encontrados alguns casos de uso literal fora do contexto de corte e costura, como em alfinetar um inseto.
} 


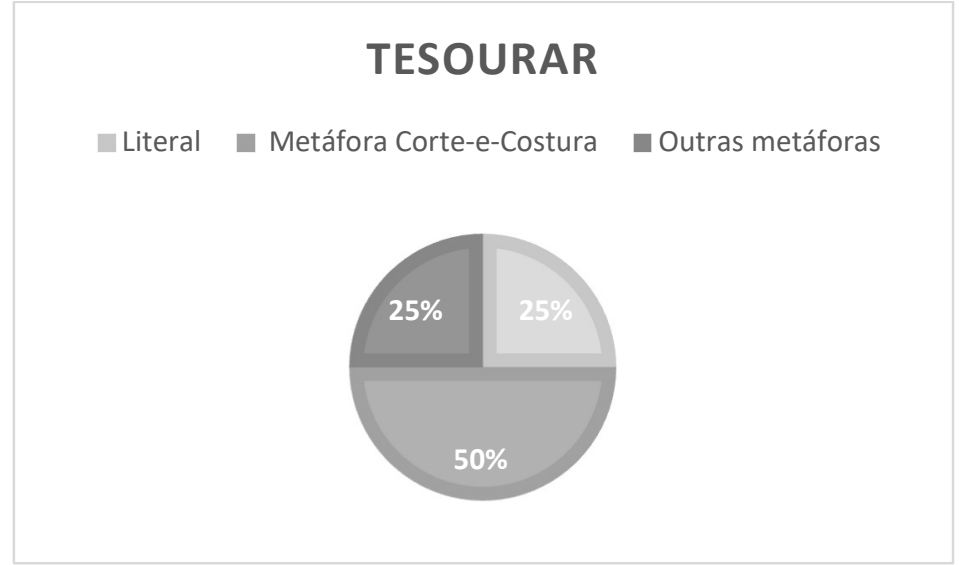

Gráfico 2- Distribuição de usos do verbo tesourar na Construção Transitiva Prototípica.

Como indica o gráfico 2, os usos literais correspondem a 25\% dos casos, como ilustra o exemplo abaixo:

(6) Menina minha irmã já me deu uma surra com uma saia de tachinha kkkkkkkkkkk Eu tesourei o vestido todinho depois (https://twitter.com/coelhodoinferno/status/1251893338988519424)

Em (6), o verbo tesourar indica a ação concreta de cortar um vestido com uma tesoura. Os usos metafóricos predominam, distribuindo-se entre extensões metafóricas envolvendo a metáfora de corte e costura $(50 \%)$ e outras extensões metafóricas $(25 \%)$. No primeiro caso, observemos o seguinte exemplo:

(7) lembrei da vez que o um amigo veio lá em casa buscar uma mochila dele e eu fiz ele tomar café com pão de queijo e passar duas horas tesourando desafetos (https://twitter.com/projetodedercy/status/1268994000209481728)

Como se observa, em (7), o uso de tesourar faz referência ao ato de falar mal dos desafetos. Trata-se, portanto, de uma extensão metafórica da construção transitiva engendrada pela metáfora de corte e costura.

Outros usos metafóricos também foram observados, entre os quais se observam extensões da metáfora TESOURAR É REDUZIR ${ }^{7}$ :

\footnotetext{
${ }^{7}$ Conforme observou um parecerista anônimo, a metáfora TESOURAR É REDUZIR está relacionada à metáfora EVENTOS SÃO OBJETOS. De fato, há uma relação hierárquica entre essas metáforas, de modo que a primeira é mais específica em relação ao nível mais esquemático EVENTOS SÃO OBJETOS, em que eventos (como narrativas e gastos) são entendidos como objetos físicos que podem ser manipulados, cortados etc. Para um
} 
(8) Tesouraram todo o começo da novela pra agora ficar nessa barriga, há dias sem acontecer nada relevante

(https://twitter.com/Angelicacrod/status/1172244608694312960)

(9) Minha mãe é uma chata às vezes, cheia de tesourar meus gastos com meu pai affffkkkkkkk (https://twitter.com/quelk3/status/782330842735579136)

Como ilustram os exemplos (8) e (9), esses usos podem se referir à não exibição de cenas de uma obra audiovisual, ou mesmo de recursos financeiros, respectivamente. ${ }^{8}$

\section{Construção Transitiva Resultativa}

Nesta seção, enfocamos a distribuição dos verbos alinhavar, costurar, tricotar e tecer com relação à Construção Transitiva Resultativa.

Observemos, inicialmente, a distribuição de alinhavar:

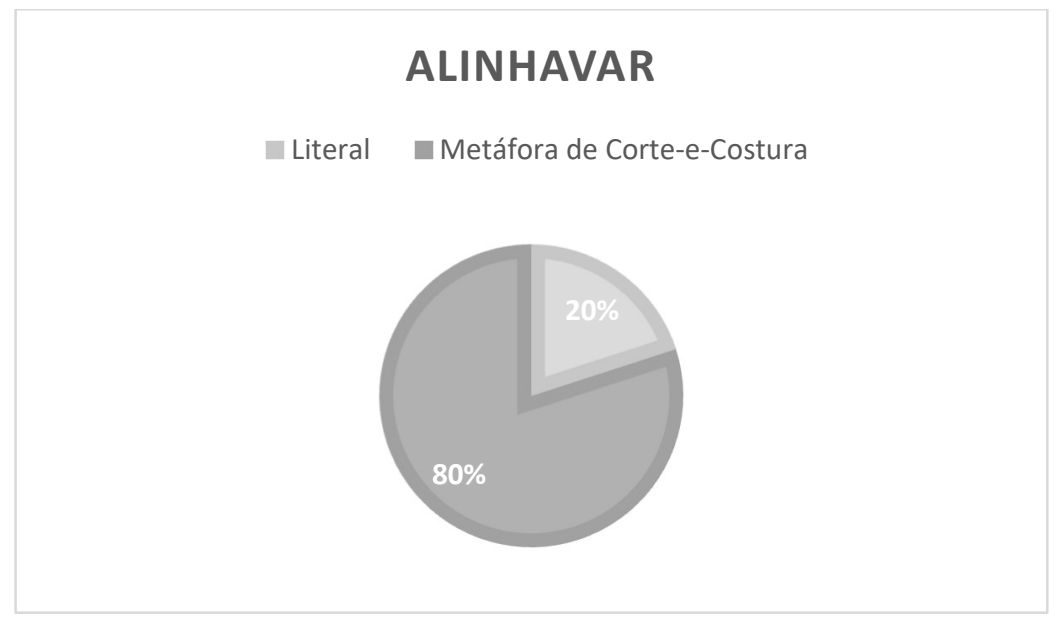

Gráfico 3- Distribuição de usos do verbo alinhavar na Construção Transitiva Prototípica.

Como demonstra o Gráfico 3, o uso literal é minoritário no corpus, ocorrendo em apenas $20 \%$ dos dados:

(10) Ajustei um pouco, deixei as peças mais certinhas e alinhavei a bainha também. Depois tenho que pedir pra alguém tirar foto pra mim. (https://twitter.com/saletasubmersa/status/1117148843907387394)

tratamento dos níveis de complexidade, mais esquemáticos ou mais específicos, de uma mesma metáfora, ver Dancygier \& Sweetser (2014, p. 49-53).

${ }^{8}$ Vale notar que, embora esses usos não estejam registrados nos dicionários consultados, corresponderam a $25 \%$ dos dados analisados. 
Já extensões metafóricas de corte e costura corresponderam a todos os outros usos metafóricos, equivalendo a $80 \%$ dos dados, conforme ilustra o exemplo a seguir:

(11) Colorado já alinhavou a negociação para comprar o meia Zé Aldo, que pertence ao Guarani de Palhoça e está emprestado até dezembro. (https://twitter.com/brunofloresrd/status/1143311985507012608)

O exemplo (11) refere-se a conversas preliminares estabelecidas entre representantes de dois clubes de futebol (Colorado e Guarani de Palhoça), para negociar a comprar do jogador Zé Aldo.

Em termos de rotinização, a extensão metafórica mais frequente nos dados é alinhavar (um) acordo, mas também são frequentes os objetos diretos apoio, estratégia, negociação, parceria, projeto, proposta, que envolvem interações comunicativas, e discurso, história, verso, que envolvem construções discursivas.

Com relação ao verbo costurar, a situação é um pouco diferente, já que os usos literais são bem mais frequentes do que os metafóricos:

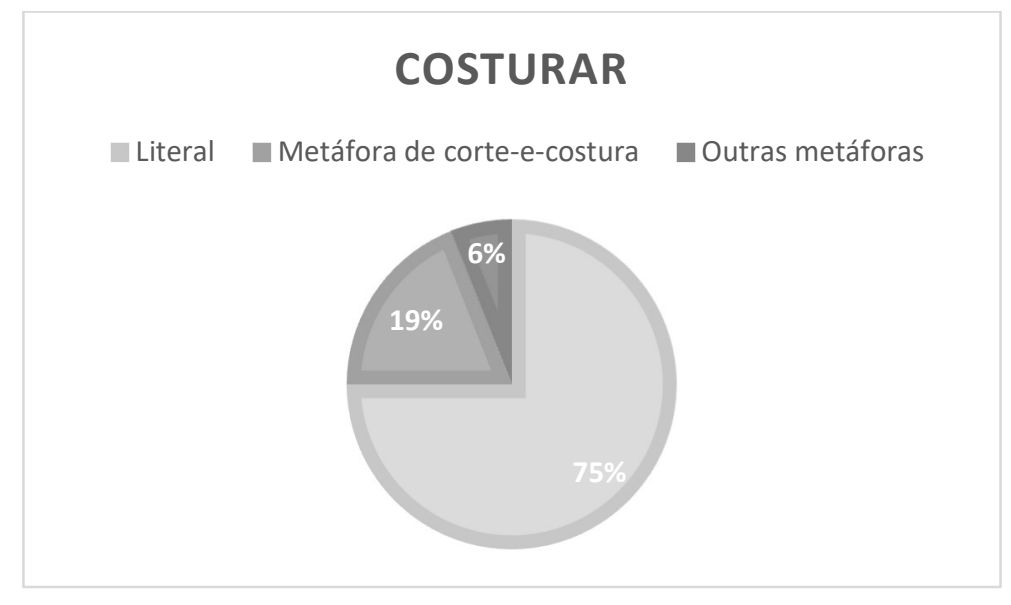

Gráfico 4 - Distribuição de usos do verbo costurar na Construção Transitiva Prototípica.

Como apontado no Gráfico 4, os usos literais correspondem a 75\% dos casos. O exemplo, a seguir, ilustra esse tipo de uso:

(12) A minha mãe é artesã aqui de Duque de Caxias (baixada fluminense) e está costurando mochilas personalizadas nesse modelo. Você pode escolher entre cores lisas, ou as estampas que ela tem disponíveis.

(https://twitter.com/_marlo7_/status/1309618038627590145) 


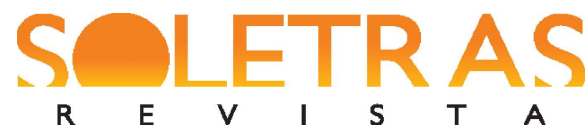

A metáfora de corte e costura é a mais frequente entre os usos metafóricos $(19 \%$ dos casos), como ilustra o exemplo a seguir:

(13) Com a reintegração de Cícero, o Botafogo costurouum acordo com o atleta. A diretoria calcula uma economia de mais de R 3 milhões. Cícero não receberá mais direitos de imagem, somente salário de CLT. (https://twitter.com/OficialPPB/status/1314664542710964225)

Em (13), a extensão metafórica de corte e costura (“o Botafogo costurou um acordo com o atleta") refere-se a um acordo já realizado entre o jogador Cícero e o clube de futebol Botafogo. Tal como com alinhavar, a expressão metafórica mais frequente tem acordo como objeto direto costurar acordo. A diferença entre as expressões parecem ser o caráter preliminar de alinhavar acordo.

A outra extensão metafórica encontrada no corpus, ainda que com frequência baixa (6\%), é MOVIMENTO EM ZIQUEZAGUE É COSTURA. Essa metáfora pode ser instanciada em contextos referentes ao trânsito ou, ainda, ao futebol:

(14) E esse motorista que tá costurando a avenida e passando os outros ônibus? Tô amando (https://twitter.com/LuciferArrasado/status/1238407458042916865)

(15) O cara costurou o meio campo do flamengo KKKKKKK (https://twitter.com/Jv_Oliveira07/status/1206994159116140549)

Enquanto o exemplo (15) busca retratar o movimento do ônibus que, para se deslocar mais rápido, vai alternando entre as pistas da avenida, o exemplo (16) faz referência aos movimentos de um jogador de futebol para driblar os jogadores do meio campo adversário. Com relação às instanciações do verbo tricotar, a distribuição é a seguinte:

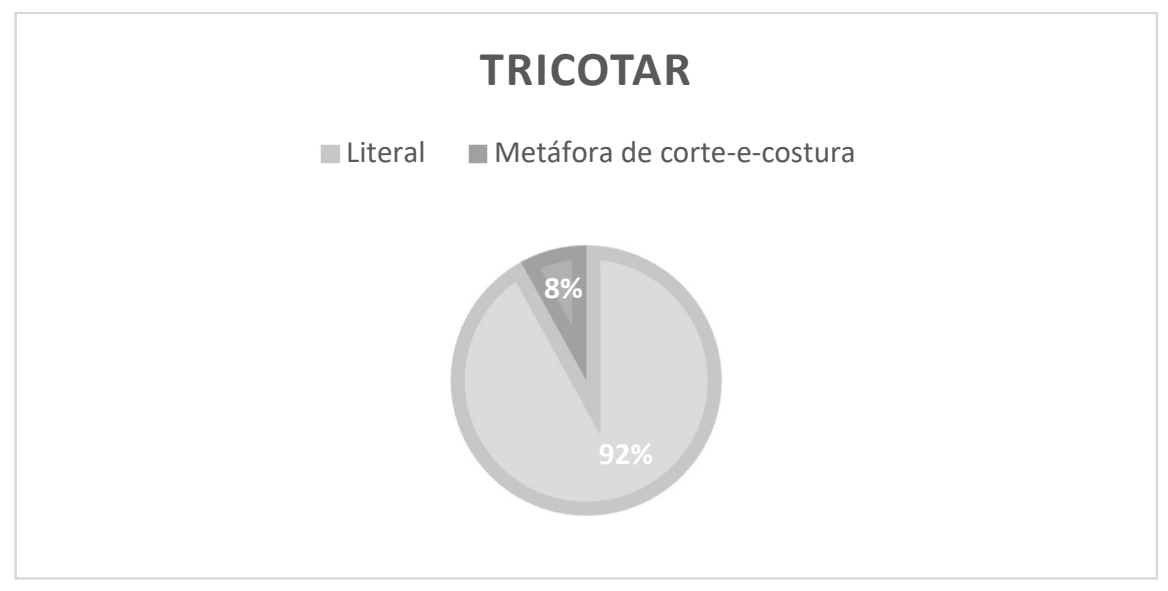


Gráfico 5 - Distribuição de usos do verbo tricotar na Construção Transitiva Prototípica.

Como indica o Gráfico 5, os usos literais são predominantes, correspondendo a $92 \%$ dos casos:

(16) tricotei esse gorrinho e agora to tricotando um cachecol pra combinar (https://twitter.com/MariaDoTOP/status/1278729488206106624)

Os usos metafóricos, por sua vez, restringem-se à metáfora de corte e costura, e pode ser ilustrada pelo exemplo a seguir:

(17) Qnd 2021 chegar já vamos começar a tricotar isso. (https://twitter.com/draselinacrf/status/1314364746573979649)

O exemplo (17) ocorre em uma conversa sobre o planejamento de uma viagem para participar da festa de São João em Campina Grande. A extensão metafórica, portanto, referese à sugestão para que se estabeleçam interações conversacionais futuras para realizar esse planejamento.

Por fim, as instanciações do verbo tecer apresentam a seguinte distribuição:

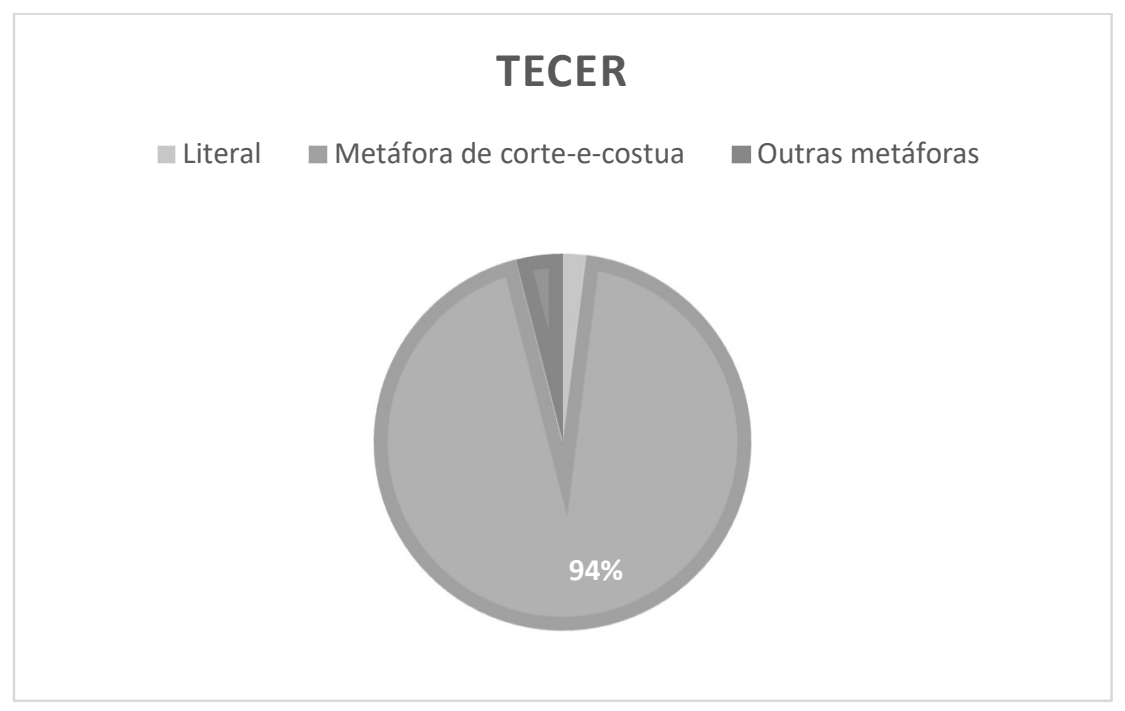

Gráfico 6 - Distribuição de usos do verbo tecer na Construção Transitiva Prototípica.

Como indica o Gráfico 6, diferentemente do que ocorre com tricotar, os usos literais de tecer são os menos frequentes, correspondendo a $2 \%$ dos casos. O exemplo a seguir ilustra esse tipo de uso: 
(18) Eu não sei quem já ensaiou uns pontos de tricô ou crochê, mas tecer uma peça (colcha, cachecol, toalha de mesa, agasalho e afins) reserva a mágica do começar sem saber onde vai dar. (https://twitter.com/nalusaad/status/1175436445777088512)

Os demais usos são metafóricos, sendo que a metáfora de corte e costura é predominante $(94 \%)$, como ilustra o exemplo a seguir:

(19) Silvia Helena também teceu elogios ao comportamento da filha e comentou sobre os conselhos que daria a ela. (https://twitter.com/Metropoles/status/1313630117818626048)

Outros usos metafóricos também ocorrem, correspondendo a 4\% dos casos. Consideremos os seguintes exemplos:

(20) E o tweet anterior é basicamente sobre isso. Sobre entender a si mesmo e reconhecer que as vozes da sua cabeça te enganam. E, acima de tudo, olhar o outro com olhos de compaixão porque, às vezes, as vozes da cabeça dele também o enganam. Confiar é escolher com quem tecer a vida. (https://twitter.com/taynna_gripp/status/1309636907484274688)

(21) a culpa, que vem da consciência intranquila, começa a tecer sua trama e afetar a vida, o sono, a produtividade (https://twitter.com/caroldemarinho/status/1313812586236960769)

No exemplo (20), a expressão tecer a vida atesta o mapeamento metafórico VIDA É TECELAGEM. Já em (21), há uma personificação, em que se retrata o sentimento de culpa como uma pessoa capaz de realizar a atividade de tecer. Trata-se, portanto, da metáfora genérica SENTIMENTO É PESSOA, a qual se articula à metáfora mais específica CULPA É TECELÃ.

\section{Considerações finais}

Este trabalho enfocou construções transitivas que permitem extensões metafóricas relacionadas à comunicação verbal, a partir da metáfora de corte e costura, que constitui um mapeamento metafórico produtivo em Português que se aplica à Construção Transitiva. Esse mapeamento engendra a extensão metafórica prototípica, em que o objeto direto é afetado pela atividade de corte e costura, e a extensão metafórica resultativa, em que o objeto direto é o resultado da ação de corte e costura. 


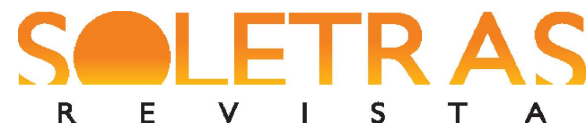

A análise da distribuição da frequência de instanciações literais e metafóricas dessas construções, a partir de dados de uso retirados do Twitter, evidenciou que as extensões metafóricas prototípicas instanciadas por alfinetar e tesourar (ex. "alfinetar ou tesourar o candidato") são mais frequentes que suas contrapartes literais (ex. "alfinetar ou tesourar o vestido"). Já as extensões metafóricas resultativas dividem-se em dois grupos: aquelas instanciadas por costurar e tricotar, em que predominam usos literais (ex. "costurar ou tricotar uma colcha") e aquelas instanciadas por alinhavar e tecer, que ocorrem predominantemente em usos metafóricos (alinhavar um acordo; tecer um comentário).

Além disso, conforme previsto na hipótese (ii), as extensões metafóricas da construção transitiva, referentes à metáfora COMUNICAÇÃO VERBAL É ATIVIDADE DE CORTE E COSTURA, são mais frequentes que outras extensões metafóricas que partem da atividade de corte e costura como domínio-fonte (VIDA É ATIVIDADE DE CORTE E COSTURA, etc.).

Embora os dados aqui apresentados sejam relativos ao Português Brasileiro, é possível que a metáfora de corte e costura, associada à comunicação verbal, também possa ser observada em outras línguas. Em especial, a presente pesquisa sugere desdobramentos futuros em que se investiguem diferentes línguas, notadamente línguas românicas e outras variedades do Português. Com relação ao Português Europeu, a metáfora também pode ser facilmente observada, mas as semelhanças e diferenças entre as duas variedades no que se refere às extensões metafóricas em questão ainda requer investigação detalhada.

\section{Referências}

BYBEE, J. Language, usage and cognition. Cambridge: Cambridge University Press, 2010.

; SCHEIBMAN, J. The effect of usage on degrees of constituency: the reduction of don't in English. Linguistics: an Interdisciplinary Journal of the Language Sciences, 37(4), 1999, p. 575-596.

CASASANTO, D. The role of language in metaphor. In: Borkent, Dancygier \& Hinnell (eds.). Language and the creative mind. Stanford, California: CSLI Publications, 2013. p. 318.

DANCYGIER, B.; SWEETSER, E. Figurative language. Cambridge: Cambridge University Press, 2014.

DIESSEL, H. Usage-based construction grammar. DRABOWSKA, E. \& DIVJAK, D. (eds.) Handbook of Cognitive Linguistics (eds.), Berlin: Mouton de Gruyter, 2015. p.295-321. 


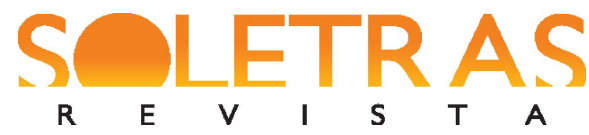

DIESSEL, H. The Grammar Network: How Linguistic Structure is Shaped by Language Use. Cambridge: Cambridge University Press, 2019.

FAUCONNIER, G. Mental spaces. Cambridge: Cambridge University Press, 1994. . Mappings in thought and language. Cambridge: Cambridge University Press, 1997.

FAUCONNIER, G.; TURNER, M. 1998. Conceptual integration networks. Cognitive Science, 22(2), p. 133-187.

. Compression and global insight. Cognitive Linguistics, 11(3-4), 2000. p. 283-304.

. The way we think: conceptual blending and the mind's hidden complexities. New York: Basic Books, 2002.

FERRARI, L.; PINHEIRO, D. Tricotar, alfinetar, rasgar o verbo: a comunicação verbal para além da metáfora do conduto. Revista Investigações, v. 28, n. 2, UFPE, p. 1-25, 2015.

FERRARI, L. Construções gramaticais, metáfora e mesclagem: a comunicação verbal como atividade de Corte e Costura. DIAS, N.B \& ABRAÇADO, J. (org.), Estudos sobre o português em uso, Uberlândia: Pangeia, p. 23-35, 2020.

FERREIRA, A. B. de H. Novo dicionário Aurélio da língua portuguesa. $2^{\mathrm{a}}$. ed. revista ampliada. Rio de Janeiro: Nova Fronteira, 1986.

FERREIRA, A. B. de H. Mini Aurélio: o dicionário da língua portuguesa / Aurélio Buarque de Holanda Ferreira; coordenação Marina Baird Ferreira. - 8. ed. rev. atual. - Curitiba: Positivo, 2010.

IBBOTSON, P.; THEAKSTON, A.; LIEVEN, E.; TOMASELlO, M. Semantics of the transitive construction: prototype effects and developmental comparison. Cognitive Science, 36, p. 1268-1288, 2012.

LAKOFF, G.; JOHNSON, M. Metaphors we live by. Chicago: The University of Chicago Press, 1980.

LANGACKER, R. Foundations of cognitive grammar: theoretical prerequisites, v. IStandford, CA: Stanford University Press, 1987.

Foundations of cognitive grammar: descriptive applications, v.II, Standford, CA: Stanford University Press, 1991.

MORRIS, P. K.; WALDMAN, J. A. Culture and metaphors in advertising: France, Germany, Italy, the Netherlands and the United States. International Journal of Communication, 5, p. 942-968, 2011.

REDDY, M. The conduit metaphor: a case of frame conflict in our language about language. ORTONY, A. (Ed.). Metaphor and thought, 2.ed. Cambridge: Cambridge University Press, [1979]1993. p.164-201. 


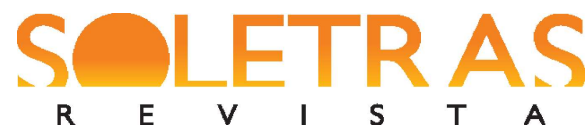

N. $41-2021.1-$ LILIAN FERRARI

CAROLINE SOARES

TURNER, M. The origin of ideas; blending, creativity and the human spark. Oxford: Oxford University Press, 2014.

\title{
Amid needles and threads: the needlework metaphor in Brazilian Portuguese
}

\begin{abstract}
This paper investigates the NEEDLEWORK METAPHOR in Brazilian Portuguese, which, as well as the largely described CONDUIT METAPHOR (REDDY, 1979), constitutes one of the possible metaphorical mappings to refer to verbal communication. Drawing on examples of naturally occurring data retrieved from Twitter, it is argued that the metaphor VERBAL COMMUNICATION IS NEEDLEWORK ACTIVITY is usually applied to the transitive construction, and gives rise to two metaphorical extensions: the prototypical transitive extension, instantiated by the verbs alfinetar (to pin) and tesourar (to snip) and the resultative metaphorical extensions, instantiated by the verbs alinhavar (to baste), costurar (to sew), tecer (to weave) and tricotar (to knit). In order to investigate the Needlework Metaphor's productivity, the analysis focuses on the frequency of literal and metaphorical senses for each group of constructions. The results show that metaphorical extensions of prototypical transitives are more frequent than their literal counterpart. On the other hand, resultative transitives can be divided in two groups: the ones instantiated by costurar (to sew) and tricotar (to knit) predominate in literal uses, whereas the ones instantiated by alinhavar (to baste) and tecer (to weave) predominate in metaphorical uses.
\end{abstract}

Keywords: verbal communication; needlework metaphor; transitive construction; metaphoric extension.

Recebido em: 22 de outubro de 2020.

Aceito em: 10 de dezembro de 2020. 